\title{
A STUDY ON FISH FEED MANUFACTURE WITH ITS NUTRITIONAL QUALITY AND IMPACTS ON FISH PRODUCTION
}

\section{Baadruzzoha Sarker*, Md. Mamunur Rahman ${ }^{1}$ and Mohammad Nurul Alam ${ }^{1}$}

Production Officer, BRAC Fish Hatchery Srimangal, Moulvibazar-3210, Bangladesh; ${ }^{1}$ Department of Aquaculture, Faculty of Fisheries, Bangladesh Agricultural University, Mymensingh-2202, Bangladesh

*Corresponding author: Baadruzzoha Sarker, E-mail: bstushar@gmail.com

\begin{tabular}{|c|c|}
\hline ARTICLE INFO & ABSTRACT \\
\hline $\begin{array}{l}\text { Received } \\
16.06 .2015 \\
\text { Accepted } \\
19.08 .2015 \\
\text { Online } \\
04.09 .2015 \\
\text { Key words } \\
\text { Fish feed } \\
\text { Production } \\
\text { Feed mill } \\
\text { Nutrition }\end{array}$ & $\begin{array}{l}\text { This study was conducted to assess the procedure of fish feed production, analysis of nutritive } \\
\text { value of feeds and its effect on growth of fish in selected fish farms. Five fish feed mills and } \\
\text { fifteen fish farmers were randomly selected from Mymensingh district. Fish feeds were used } \\
\text { by fifteen farmers among every three farmers used the feed of each mill. These feed Mills } \\
\text { collect their Saudi Bangla and ACME fish feed are more preferable to the farmer due to higher } \\
\text { protein and lipid content resulting more fish production. In this experiment, Saudi-Bangla fish } \\
\text { feed mill ( } 3843 \mathrm{Kg} / \mathrm{ha} / \mathrm{yr} \text { ), Sunny fish feed mill ( } 3761 \mathrm{Kg} / \mathrm{ha} / \mathrm{yr} \text { ), Shushama fish feed mill ( } 3581 \\
\mathrm{Kg} / \mathrm{ha} / \mathrm{yr} \text { ), Al-momen fish feed mill ( } 3669 \mathrm{Kg} / \mathrm{ha} / \mathrm{yr} \text { ), ACME fish feed mill ( } 3796 \mathrm{Kg} / \mathrm{ha} / \mathrm{yr} \text { ) was } \\
\text { produce fish. Capital cost, operating cost, depreciation cost, total cost, revenue income and } \\
\text { net profit were calculated and evaluated during the experimental period. In this study, those } \\
\text { feed mills production capacity was } 45000 \text { ton/yr Saudi-Bangla fish feed mill, } 45000 \text { ton/yr } \\
\text { Sunny fish feed mill, } 35000 \text { ton/yr Shushomo fish feed mill, } 35000 \text { ton/yr Al-momen fish feed } \\
\text { mill, } 15000 \text { ton/yr ACME fish feed mill. The fish production mainly carps and pangus were } \\
\text { highly occurs chronologically Saudi-Bangla, ACME fish feed, Sunny fish feed, Al-momen fish } \\
\text { feed, Shushama fish feed mill, respectively. Among those the nutritive value of Saudi-Bangla } \\
\text { fish feed was the best than other fish feed. }\end{array}$ \\
\hline
\end{tabular}

To cite this article: B Sarker, MM Rahman and MN Alam, 2015. A study on fish feed manufacture with its nutritional quality and impacts on fish production. Res. Agric. Livest. Fish. 2 (2): 353-362.

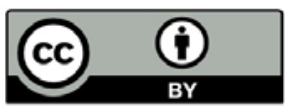

This is an open access article licensed under the terms of the Creative Commons Attribution 4.0 International License

www.agroaid-bd.org/ralf, E-mail: editor.ralf@gmail.com 


\section{INTRODUCTION}

The primary conditions for intensification of any culture depend on the natural and artificial feed. With the progress of technology and increasing demand different types of improved culture technique are now being practiced in our country. As a result huge quantity of supplementary feed has to provide to the cultured species. The demand has increased 1.5 times greater than the previous five years. So the prospect of aqua feed industry is very bright in our country. It is evident that for the proper nourishment of fish a balanced diet containing energy sources-with all essential fatty acids, protein-with all essential amino acids, vitamins and minerals are very vital. With the increasing demand of feed, many companies have established feed industry in different parts of the country. The popular feed companies in the market are Saudi Bangla Feed (Mymensingh), Quality Fish Feed (Gazipur), Aftab Feed (Dhaka), CP fish feed (Thailand), Paragon fish feed, Fresh Fish Feed (Dhaka), Niribili Feed (Cox's Bazar), Usha Feed (Jessore), Premium Feed (Jessore), Excel Feed (Dhaka), Titas Feed (Khulna),North Khulna Feed (Khulna), etc. Saudi Bangla Fish Feed, Sunny Fish Feed, ACME Fish Feed, Al-amin Fish feed Industries have become very popular in producing aqua feed in Mymensingh region.

A huge number of people of Mymensingh region are involved in aqua feed industries. However fish are fastidious eater in that, they require higher levels of dietary protein. Feed stuffs of vegetable origin are lower protein content compared with animal origin. An International Network of Feed Information Centre has been established a nutrients profile of feed stuffs which is maintain in many countries around the world. In Bangladesh, a large variety of indigenous raw materials and agricultural wastes which are rich in nutrients ultimately go waste without being properly utilized for useful purpose. Some of these are: fish meal, frog waste meal, oil cake, rice and wheat bran, leaves and vegetables, other animal and agricultural wastes. However, detail information about their availability, economy and biochemical composition are yet to be fully known. Knowing this information a systematic approach towards a sound and effective formulation and manufacture of fish feed from local ingredients can be made. The study might help, how to formulate and manufacture of the fish feed, quality of the feed, effects on fish growth, and some recommendation would be made which would help to improve the fish production and also awareness the farmer to know about good quality fish feed use in their aqua farms. The research has been undertaken to know about raw materials and production process of fish feed in selected feed mills, to evaluate the effect of feed on fish growth in various aqua farms and to analyze the cost benefit ratio in different aqua farms.

\section{MATERIALS AND METHODS}

\section{Fish feed ingredients}

The selected sites for data collection were located at major fish feed mills of Mymensingh region. The raw materials are commonly use in the feed mills were fish meal, dry trash fish, soybean meal, rapeseed, rice polish, mould inhibitor, vitamin premix, calcium and phosphorus, salt, meats bone meal, Di-calcium phosphate, non-antibiotic growth promoter, de-oiled DORB, choline chloride, vitamin, binder etc. This of ingredients used in selected five different feed mills.

\section{Feed production}

Different fish feed mill produce different types of feed. Feed production at five different feed mills is shown below in Table 1.

\section{Collection and preparation of feed samples}

The most popular commercial fish feeds are Saudi-Bangla fish feed, Sunny fish feed, Shushama fish feed, Almomen fish feed mill and ACME fish feed. Starterand grower feeds used in this study were collected directly from interviewed fish farmers. The samples were taken from the refrigerator and kept in room temperature for few hours. Then the required amount of samples were finely ground by a mortar and kept in airtight container for subsequent chemical analysis. The analysis of feed was carried out in the Fish Nutrition Laboratory of the department of aquaculture in the Faculty of Fisheries, Bangladesh Agricultural University (BAU), Mymensingh. The laboratory had available facilities for the determination of proximate composition viz. moisture, crude protein, crude lipid, ash, crude fiber and carbohydrate. The proximate composition of different commercial fish feeds were analyzed in duplicate according to standard procedure given in Association of Official Analytical Chemists (AOAC, 2000). 
Table 1. Feed production at five different feed mills

\begin{tabular}{llllll}
\hline Feed name & $\begin{array}{l}\text { Saudi-Bangla } \\
\text { fish feed mill }\end{array}$ & $\begin{array}{l}\text { Sunny fish } \\
\text { feed mill }\end{array}$ & $\begin{array}{l}\text { Shushomo } \\
\text { fish feed mill }\end{array}$ & $\begin{array}{l}\text { Al-momen fish } \\
\text { feed mill }\end{array}$ & $\begin{array}{l}\text { ACME fish } \\
\text { feed mill }\end{array}$ \\
\hline Starter-1 & Produce & Produce & Produce & Produce & Produce \\
Starter-2 & Produce & Produce & Produce & Produce & Produce \\
Starter-3 & Produce & Produce & Produce & Produce & Produce \\
Grower & Produce & Produce & Produce & Produce & Produce \\
Sinking & Produce & Produce & Produce & Produce & Produce \\
Floating feed & - & - & - & - & - \\
Poultry feed & - & Produce & - & Produce & - \\
Cattle feed & - & - & - & - & - \\
Duck feed & - & - & - & - & - \\
Other feed & - & & & - & - \\
\hline
\end{tabular}

\section{Processing and analysis of data}

After the data collection, the collected data were summarized, tabulated and analyzed according to the objectives of the study. A tabular method of analysis was followed in analyzing the collected information.

\section{Fish production}

\section{Location and selection of target fish farmers}

The selected sites were located at fish farmer of Mymensingh region in Bangladesh. Various categories of fish farmers were selected on the basis use of different mills feed. Fifteen fish farmers randomly selected of which three users from each feed mill.

\section{Cost Benefit Analysis}

Total operating cost

The total operating cost was calculated by using the following formula:

Total operating cost $=$ Human labor cost + Fingerling cost + Feed cost + Fertilizer cost + Fish poison + Lime + Miscellaneous.

\section{Depreciation}

The depreciation cost was calculated using the following formula:

Annual depreciation cost $=\frac{\text { Fixed } / \text { capital cost }- \text { Salvage value }}{\text { Useful life }}$.

\section{Total capital cost}

The total capital cost was calculated by using the following formula:

Total capital cost $=$ Land used cost + Bank interest

\section{Total cost}

The total cost was calculated by using the following formula:

Total cost $=$ Total capital cost + Total Operating cost 


\section{Revenue income}

The revenue income was calculated using the following formula:

Revenue income $(B D T)=$ Production $(\mathrm{kg}) \times$ Unit price $(B D T)$

\section{Net Profit}

The net profit was calculated using the following formula:

Net profit $=$ Total revenue income - Total cost

\section{Cost Benefit Ratio}

The cost benefit ratio was calculated by using the following formula:

Cost Benefit Ratio $=\frac{\text { Total benefits }}{\text { Total cost }}$

\section{RESULTS AND DISCUSSION}

\section{Fish feed production}

Cost and collection of ingredients are shown in Table 2.

Table 2. Average raw material costs of fish feed production

\begin{tabular}{lll}
\hline Item & Source & Price/Kg \\
\hline Fish meal & Own country & 50 \\
Dry trash fish & Own country & 40 \\
Rice polish & Own country & 18 \\
Vitamin premix & Own country & 225 \\
Calcium and phosphorus & Own country & 9 \\
Salt (NaCl) & Own country & 8 \\
De-oiled DORB & Own country & 15 \\
Binder & Own country & 30 \\
Non-antibiotic growth promoter & Other country & 296 \\
Meats bone meal & Other country & 26 \\
Die calcium phosphate & Other country & 40 \\
Rape seed & Other country & 19 \\
Mould inhibitor & Other country & 38 \\
Choline chloride & Other country & 36 \\
Soybean meal & Other country & 37 \\
\hline
\end{tabular}

\section{Nutritional composition of different fish feed:}

Nutrition is the most important factors of fish feed. Appropriate nutritional composition help to fish perfectly growth. Nutritional compositions vary species to species, size to size and age to age of fish. 
Table 3. Capacities of different types of fish feed mills

\begin{tabular}{llllll}
\hline Mill No. & $\begin{array}{l}\text { Installed } \\
\text { capacity } \\
\text { (ton/yr) }\end{array}$ & $\begin{array}{l}\text { Actual production } \\
\text { (June, 2010-June, 2011) } \\
\text { (ton/yr) }\end{array}$ & $\begin{array}{l}\text { Average } \\
\text { Price } \\
\text { (ton) }\end{array}$ & $\begin{array}{l}\text { Total sale of } \\
\text { feed (BDT) }\end{array}$ & $\begin{array}{l}\text { Percent of } \\
\text { capacity } \\
\text { utilization }\end{array}$ \\
\hline $\begin{array}{l}\text { Saudi-Bangla fish } \\
\text { feed mill }\end{array}$ & 45000 & 34997 & 29475 & 1031547509 & 77.77 \\
$\begin{array}{l}\text { Sunny fish feed } \\
\text { mill }\end{array}$ & 45000 & 31273 & 29967 & 937210150 & 69.50 \\
$\begin{array}{l}\text { Shushama fish } \\
\text { feed mill }\end{array}$ & 35000 & 24500 & 29466 & 721906776 & 70.00 \\
$\begin{array}{l}\text { Al-momen fish } \\
\text { feed mill }\end{array}$ & 35000 & 24197 & 29962 & 724984605 & 69.14 \\
$\begin{array}{l}\text { ACME fish feed } \\
\text { mill }\end{array}$ & 15000 & 9842 & 28945 & 284904500 & 65.61 \\
Average & 35000 & 24962 & - & - & 70.40 \\
\hline
\end{tabular}

Table 4. Nutritional composition of different fish feed.

\begin{tabular}{lllllllllll}
\hline \multirow{2}{*}{ Mill No. } & $\mathbf{1}$ & \multicolumn{3}{c}{$\mathbf{2}$} & \multicolumn{3}{c}{$\mathbf{3}$} & \multicolumn{3}{c}{$\mathbf{4}$} \\
\cline { 2 - 11 } & Starter & Growe & Starte & Growe & Starte & Growe & Starte & Growe & Starte & Growe \\
& $(\%)$ & $r(\%)$ & $r(\%)$ & $r(\%)$ & $r(\%)$ & $r(\%)$ & $r(\%)$ & $r(\%)$ & $r(\%)$ & $r(\%)$ \\
\hline Moisture & 10.06 & 11.03 & 12.66 & 12.31 & 12.29 & 8.49 & 12.36 & 14.30 & 12.17 & 11.26 \\
Lipid & 7.60 & 4.32 & 5.02 & 8.36 & 9.69 & 10.49 & 7.21 & 7.38 & 8.61 & 9.75 \\
Crude Prorein & 27.89 & 25.66 & 24.27 & 22.00 & 27.52 & 24.37 & 25.62 & 23.18 & 26.09 & 24.70 \\
Ash & 16.76 & 14.40 & 19.90 & 15.47 & 14.75 & 21.13 & 13.48 & 16.11 & 21.17 & 20.88 \\
Crude Fibre & 5.80 & 6.05 & 6.45 & 7.56 & 5.45 & 6.85 & 4.26 & 5.85 & 6.05 & 6.40 \\
Carbohydrate & 31.89 & 38.54 & 31.70 & 34.30 & 30.30 & 28.67 & 37.07 & 33.18 & 25.91 & 27.01 \\
\hline
\end{tabular}

1. Saudi-Bangla fish feed mill, 2. Sunny fish feed mill, 3. Shushama fish feed mill, 4. Al-momen fish feed mill,

5. ACME fish feed mill

\section{Estimation of returns}

Most of the fish farmers were trained by different organization and they are accustomed to keeping record of their fish farming expenditure and economic returns. Pond books maintained by the fish farmers helped the researcher to get reliable information about the existing fish production ( $\mathrm{kg} / \mathrm{ha} / \mathrm{yr})$ in the locality. Species and fish feed mill wise average fish productions in the surveyed areas are given below. 
Fish production by fish farmers

Table 5. Costs per hectare of fish ponds

\begin{tabular}{llcccccc}
\hline Cost items & $\mathbf{1}$ & $\mathbf{2}$ & $\mathbf{3}$ & $\mathbf{4}$ & $\mathbf{5}$ & $\begin{array}{c}\text { Cost } \\
\text { ( Tk/ha) }\end{array}$ & $\begin{array}{l}\text { Percent } \\
\text { (\%) }\end{array}$ \\
\hline $\begin{array}{l}\text { Operating cost } \\
\text { Human labor cost }\end{array}$ & 2500 & 2700 & 3000 & 2900 & 2900 & 14000 & 9.34 \\
Fingerling cost & 4000 & 4000 & 3000 & 3000 & 3500 & 17500 & 11.67 \\
Feed cost & 9800 & 9880 & 9960 & 9880 & 9880 & 49400 & 32.96 \\
Fertilizer cost & 4517 & 3755 & 4000 & 3500 & 3000 & 18772 & 12.52 \\
Fish poison & 500 & 500 & 500 & 500 & 500 & 2500 & 1.66 \\
Lime & 1015 & 1010 & 965 & 950 & 1000 & 4940 & 3.29 \\
Miscellaneous & 300 & 500 & 400 & 400 & 400 & 2000 & 1.40 \\
A. Total variable cost & 22632 & 22345 & 21825 & 21130 & 21180 & 109112 & 72.80 \\
Capital cost & & & & & & & 160 \\
Land use cost & 5000 & 4500 & 5300 & 5000 & 4900 & 24700 & 16.48 \\
Bank interest & 3865 & 3115 & 3000 & 2866 & 3211 & 16057 & 10.72 \\
B. Total fixed cost & 8865 & 7615 & 8300 & 7866 & 8111 & 40757 & 27.19 \\
Total gross cost & 31497 & 29960 & 30125 & 28996 & 29291 & 149869 & 100 \\
(A+B) & & & & & & & \\
\hline
\end{tabular}

1. Saudi-Bangla fish feed mill, 2. Sunny fish feed mill, 3. Shushama fish feed mill, 4. Al-momen fish feed mill, 5. ACME fish feed mill

Table 6. Fish production (kg/ha) used by Saudi-Bangla fish feed mill

\begin{tabular}{lllll}
\hline Species of fish & $\begin{array}{l}\text { Average production } \\
\text { (kg/ha) }\end{array}$ & $\begin{array}{l}\text { Final weight } \\
\mathbf{( g )}\end{array}$ & $\begin{array}{l}\text { Average price } \\
\text { (Tk/kg) }\end{array}$ & $\begin{array}{l}\text { Total price } \\
\text { (Tk) }\end{array}$ \\
\hline Rui & 657 & $300-800$ & 95 & 62415 \\
Catla & 311 & $400-600$ & 90 & 27990 \\
Mrigal & 367 & $300-500$ & 85 & 31195 \\
Bata & 157 & $100-200$ & 110 & 17270 \\
Silver carp & 610 & $500-800$ & 80 & 48800 \\
Grass carp & 251 & $500-900$ & 90 & 22590 \\
Pangas & 712 & $500-800$ & 75 & 53400 \\
Tilapia & 620 & $200-500$ & 100 & 62000 \\
Sarpunti & 158 & $120-200$ & 90 & 14220 \\
Total & 3843 & & & 339880 \\
\hline
\end{tabular}

Table 7. Fish production (kg/ha) used by Sunny fish feed mill

\begin{tabular}{lllll}
\hline Species of fish & $\begin{array}{l}\text { Average production } \\
\text { (kg/ha) }\end{array}$ & $\begin{array}{l}\text { Final weight } \\
\mathbf{( g )}\end{array}$ & $\begin{array}{l}\text { Average price } \\
\text { (Tk/kg) }\end{array}$ & $\begin{array}{l}\text { Total price } \\
\text { (Tk) }\end{array}$ \\
\hline Rui & 635 & $250-750$ & 95 & 60325 \\
Catla & 298 & $350-500$ & 90 & 26820 \\
Mrigal & 375 & $250-400$ & 85 & 31875 \\
Bata & 120 & $100-150$ & 110 & 13200 \\
Silver carp & 690 & $400-600$ & 80 & 55200 \\
Grass carp & 203 & $400-700$ & 90 & 18270 \\
Pangas & 680 & $300-600$ & 75 & 51000 \\
Tilapia & 610 & $400-600$ & 100 & 61000 \\
Sarpunti & 150 & $100-150$ & 90 & 13500 \\
Total & 3761 & - & - & 331190 \\
\hline
\end{tabular}


Table 8. Fish production ( $\mathrm{kg} / \mathrm{ha})$ used by Shushama fish feed mill

\begin{tabular}{lllll}
\hline Species of fish & $\begin{array}{l}\text { Average production } \\
(\mathbf{k g} / \mathbf{h a})\end{array}$ & $\begin{array}{l}\text { Final weight } \\
\mathbf{( g )}\end{array}$ & $\begin{array}{l}\text { Average price } \\
\text { (Tk/kg) }\end{array}$ & $\begin{array}{l}\text { Total price } \\
\text { (Tk) }\end{array}$ \\
\hline Rui & 580 & $300-650$ & 95 & 55100 \\
Catla & 295 & $400-500$ & 90 & 26550 \\
Mrigal & 355 & $300-500$ & 85 & 30175 \\
Bata & 170 & $100-160$ & 110 & 18700 \\
Silver carp & 550 & $300-500$ & 80 & 44000 \\
Grass carp & 230 & $400-600$ & 90 & 20700 \\
Pangas & 658 & $300-650$ & 75 & 49350 \\
Tilapia & 580 & $350-600$ & 100 & 58000 \\
Sarpunti & 163 & $100-120$ & 90 & 14670 \\
Total & 3581 & & & 317245 \\
\hline
\end{tabular}

Table 9. Fish production ( $\mathrm{kg} / \mathrm{ha}$ ) used by Al-momen fish feed mill

\begin{tabular}{|c|c|c|c|c|}
\hline Species of fish & $\begin{array}{l}\text { Average } \\
\text { production (kg/ha) }\end{array}$ & Final weight (g) & $\begin{array}{l}\text { Average price } \\
\text { (Tk/kg) }\end{array}$ & Total price (Tk) \\
\hline Rui & 660 & $400-600$ & 95 & 62700 \\
\hline Catla & 310 & $350-600$ & 90 & 27900 \\
\hline Mrigal & 386 & $400-550$ & 85 & 32810 \\
\hline Bata & 120 & $100-140$ & 110 & 13200 \\
\hline Silver carp & 550 & $250-400$ & 80 & 44000 \\
\hline Grass carp & 223 & $300-500$ & 90 & 20070 \\
\hline Pangas & 670 & $300-600$ & 75 & 50250 \\
\hline Tilapia & 580 & $400-600$ & 100 & 58000 \\
\hline Sarpunti & 170 & $100-150$ & 90 & 15300 \\
\hline Total & 3669 & & & 324230 \\
\hline
\end{tabular}

Table 10. Fish production (kg/ha) used by ACME fish feed mill

\begin{tabular}{lllll}
\hline Species of fish & $\begin{array}{l}\text { Average production } \\
\text { (kg/ha) }\end{array}$ & $\begin{array}{l}\text { Final weight } \\
(\mathbf{g})\end{array}$ & $\begin{array}{l}\text { Average price } \\
\text { (Tk/kg) }\end{array}$ & $\begin{array}{l}\text { Total price } \\
\text { (Tk) }\end{array}$ \\
\hline Rui & 668 & $250-700$ & 95 & 63460 \\
Catla & 288 & $300-600$ & 90 & 25920 \\
Mrigal & 380 & $200-500$ & 85 & 32300 \\
Bata & 167 & $100-200$ & 110 & 18370 \\
Silver carp & 539 & $500-800$ & 80 & 43120 \\
$\quad$ Grass carp & 251 & $500-900$ & 90 & 22590 \\
Pangas & 750 & $400-800$ & 75 & 56250 \\
Tilapia & 590 & $200-500$ & 100 & 59000 \\
Sarpunti & 163 & $120-200$ & 90 & 14670 \\
Total & 3796 & & & 335680 \\
\hline
\end{tabular}


Yield

It appears from five fish feed mills in Table-8 to Table-12 that the average production of fish used by five feed mills feed represent 3843, 3761, 3581, 3669 and $3796 \mathrm{~kg} / \mathrm{ha} / \mathrm{yr}$ respectively.

\section{Gross return}

Gross return is the value of fish produced in money terms. This is calculated by multiplying the total amount of production by their respective market prices. Gross return from fish production were 339880 , $331190,317245,324230$ and $335680 \mathrm{Tk} /$ ha respectively.

\section{Net return}

Per hectare net returns from fish production was calculated by deducting gross costs from gross returns. It can be noted that per hectare net return were Tk 190011, 181321, 167376, 174361, and 185811, respectively.

\section{Cost Benefit Ratio (BCR)}

Cost benefit ratio of fish farm were 2.26, 2.20, 2.11, 2.16, 2.23 for five groups of fish farmers who used feeds of five different feed mills. Among them Saudi-Bangla feed user farmers and ACME feed users farmers got highest profit than others. The finding justifies that benefit ratio was higher than one, suggesting that there is a bright potential for fish development used by above five mills feed.

Sustainability of fish feed mills and fish farming enterprise mainly depends on its economic viability and profitability. A simple cost and return analysis were done on the basis of both cost and full cost to determine the profitability fish feed and pond fish production was highly profitable business (Zaher and Mazid 1993). Use of higher level of inputs usually results in higher outputs, consequently higher investments produces higher gross and net return on per unit water body of ponds (Rahman, 1995; Biswas, 1990). Higher net return from the pond fish production is influenced by the price of outputs and economic use of both material inputs and labor (Rahman, 1995). On the other hand, Shohel (1998) reported that the fish production is largely influenced by a combination of fish seed, fish feed and the number of fingerling stocking. The average Installed capacity of different fish feed mills 35,000 (ton/yr), Processing capacity 24,962 (ton/yr), Percent of capacity utilization $70.40 \%$. To increase more production need to increase the different capacities. FAO (2005) designed a survey on the formulated animal and aqua feeds industry in sub-Saharan Africa. This document contains five country reviews (South Africa, Nigeria, Cote d'Ivoire, Kenya and Zambia) and one regional synthesis paper on the animal and aqua feed industry in sub-Saharan Africa. The mean moisture value starter and grower feed were of Saudi Bangla fish feed Sunny fish feed mill, Shushuma fish feed mill , Al-momen fish feed mill and ACME fish feed mill are 10.06\%, 12.66\%, 12.29\%, 12.36\%, 12.17\% and $11.03 \%, 12.31 \%, 8.49 \%, 14.30 \%, 11.26 \%$ respectively. Maximum moisture content starter feed in Sunny fish feed was $12.66 \%$, minimum moisture content starter feed in Saudi-Bangla fish feed was 10.06\%. Maximum moisture content grower Al-momen fish feed was $14.30 \%$, minimum moisture content starter feed in Saudi-Bangla fish feed was $8.49 \%$. Dry feeds contain $8-10 \%$ moisture while the water content of moist feed ranges from 17 to $40 \%$ or more (Lall, 1991). Roy (2002) reported that a diet containing 9.8\% moisture appears to be more suitable for GIFT tilapia, which was more or less similar with the present findings.

The mean crude protein value of ACl fish feed, Fresh fish feed, Mega fish feed, Aftab fish feed, CP fish feed, Saudi Bangla fish feed and Quality fish feed are $23.15 \%, 23.92 \%, 24.24 \%, 25.85 \%, 23.74 \%, 26.65 \%$ and $31.67 \%$, respectively. Minimum crude protein content was found in $\mathrm{ACl}$ fish feed $(23.15 \%)$ and maximum crude protein was in Quality fish feed $31.67 \%$. In ACl fish feed crude protein was high because lipid was low. The protein requirement of fish is influenced by various factors such as fish size, water temperature, feeding rate, availability and quality of natural foods, overall digestible energy content of diet. Roy (2002) reported that a diet containing $27.87 \%$ protein appears to be more suitable for GIFT tilapia. The mean crude lipid values of starter and grower feed were of Saudi Bangla fish feed, Sunny fish feed mill, Shushuma fish feed mill, Almomen fish feed mill and ACME fish feed mill are 7.60\%, 5.02\%, 9.69\%, 7.21\%, 8.61\%, and 4.32\%, 8.36\%, $10.49 \%, 7.38 \%, 9.75 \%$ respectively. Maximum crude lipid of starter feed found in Shushama fish feed $9.69 \%$ and minimum crude lipid of starter feed found in Sunny fish feed $5.02 \%$. There is an inverse relationship between protein and lipid content. Maximum crude lipid of grower feed found in Shushama fish feed $10.49 \%$ and minimum crude lipid of grower feed found in Saudi-Bangla fish feed $4.32 \%$. There is an inverse relationship between protein and lipid content. Lipid content might be low due to improper storage facilities. 
Roy (2002) reported that a diet containing $9.48 \%$ lipid appears to be more suitable for GIFT tilapia, which was more or less similar with the present findings. The mean ash values of starter and grower feed were of Saudi Bangla fish feed, Sunny fish feed mill, Shushuma fish feed mill , Al-momen fish feed mill and ACME fish feed mill are $16.76 \%, 19.90 \%, 14.75 \%, 13.48 \%, 21.17 \%$, and $14.40 \%, 15.47 \%, 21.13 \%, 16.11 \%, 20.88 \%$ respectively. Maximum ash of starter feed found in ACME fish feed $21.17 \%$ and minimum ash of starter feed found in Al-momen fish feed 13.48\%. Maximum crude lipid of grower feed found in Shushama fish feed $21.13 \%$ and minimum ash of grower feed found in Saudi-Bangla fish feed $14.40 \%$. Bhuiyan (2002) found that the diet containing $11.02 \%$ ash appears to be more suitable for carp polyculture. Roy (2002) reported that a diet containing $12.92 \%$ ash appears to be more suitable for GIFT tilapia, which was more or less similar with the present findings. The mean crude fibre values of starter and grower feed were of Saudi Bangla fish feed, Sunny fish feed mill, Shushuma fish feed mill , Al-momen fish feed mill and ACME fish feed mill are 5.80\%, $6.45 \%, 5.45 \%, 4.26 \%, 6.05 \%$, and $6.05 \%, 7.56 \%, 6.85 \%, 5.85 \%, 6.40 \%$ respectively. Maximum crude fibre of starter feed found in Sunny fish feed $6.45 \%$ and minimum crude fibre of starter feed found in Al-momen fish feed $4.26 \%$. Maximum crude fibre of grower feed found in Sunny fish feed $7.56 \%$ and minimum crude fibre of grower feed found in Al-momen fish feed $5.85 \%$. Roy (2002) reported that a diet containing $10.75 \%$ crude fiber appears to be more suitable for GIFT tilapia. A certain amount of fiber in feed permits better binding and moderates the passage of feed through alimentary canal. However, it is not desirable to have a fiber content exceeding $8-12 \%$ in diets for fish, as the increase in fiber content would consequently result in the decrease of the quality of an unusable nutrient in the diet (De Silva and Anderson, 1995), which was lower than the present findings. The mean carbohydrate values of starter and grower feed were of Saudi Bangla fish feed, Sunny fish feed mill, Shushuma fish feed mill , Al-momen fish feed mill and ACME fish feed mill are $31.89 \%$, $31.70 \%, 30.30 \%, 37.07 \%, 25.91 \%$, and $38.54 \%, 34.30 \%, 28.67 \%, 33.18 \%, 27.01 \%$, respectively. Maximum carbohydrate of starter feed found in Shushama fish feed $37.07 \%$ and minimum carbohydrate of starter feed found in ACME fish feed 25.91\%. Maximum carbohydrate of grower feed found in Saudi-Bangla fish feed $38.54 \%$ and minimum carbohydrate of grower feed found in ACME fish feed $27.01 \%$. Ali (2008) found that the diet containing $13 \% \mathrm{CHO}$ appears to be more suitable for Nile tilapia. Bhuiyan (2002) found that the diet containing $34.53 \% \mathrm{CHO}$ appears to be more suitable for carp polyculture. Roy reported that a diet containing $29.18 \% \mathrm{CHO}$ appears to be more suitable for GIFT tilapia, which was more or less similar with the present findings. Cost Benefit Ratio (CBR) is an important indicator about the profitability of fish culture operation. The benefit cost ratio was found to be 1.84 in the present study. A much similar level of CBR was noted RMC (1995) for credit, contact and demonstration farmers of Mymensingh Aquaculture Extension Project (MAEP). Shohel (1990) estimated the value of CBR to be 2.02 which revealed that for investment of 1.00 taka, the economic return is 2.02 taka.In this study, the CBR valve of Saudi-Bangla Fish Feed mill, Sunny Fish Feed mill, Shoshomo Fish Feed mill, Al-momen Feed mill and ACME Fish Feed mill was 2.26, 2.20, 2.11, 2.16 and 2.23 respectively.This is more or less similar with Shohel (1990).Studies conducted by other researchers (Islam, 1987; Islam and Dewan, 1987; Rahman, 1995; Amin, 1998; Shohel, 1998; Rahman, 1998) indicated that fish production under mono and polyculture systems were highly profitable. For polyculture (per hectare per year) gross cost, gross income and net return stood at Tk. 149869, 275185 and 125316 respectively. These levels of lucrative economic return were possible due to use of scientific method and efficient management of material inputs of different fish feed mill. Saudi-Bangla fish feed mill (gross cost, gross income and net return stood at Tk. 31497, 339880 and 190011), Sunny fish feed mill (gross cost, gross income and net return stood at Tk. 29960, 331190 and 181321 ), Shushomo fish feed mill (gross cost, gross income and net return stood at Tk. 30125, 317245and 167376 ), Al-momen fish feed mill (gross cost, gross income and net return stood at Tk. 28996, 324230 and 174361), ACME fish feed mill (gross cost, gross income and net return stood at Tk. 335680,29291 and 185811).Biswas (1990) reported to have achieved fish yield as high as $4534 \mathrm{~kg} / \mathrm{ha} / \mathrm{yr}$ from carp polyculture with gross and net return of Tk. 47680 and Tk. 37910 per hectare, respectively. A similar level of yield was also reported by Khaleque et al. (1998) from Kishoregonj and Mymensingh districts. Average fish production cost, gross return and net return determined by Khaleque et al. (1998) were the Tk. 86916 Tk. 166350 and Tk. 79437 ha/yr respectively. Educational status of the fish feed mill owner and fish farmer plays a vital role for the proper management and utilization of the new technology. Fish feed production is a sensitive and profitable business for this reason the every people of this sector to know proper knowledge of feed production, distribution and uses. 


\section{CONCLUSION}

This study was based on questionnaire interview on fish feed mills and fish farmers in Mymensingh region. Fish feeds were used by fifteen farmers among which every three farmers used the feed of each company. All the fish feed mill and fish farm were randomly selected from the study area. The study was conducted from July to September, 2011. This study might help in different ways to enhance quality fish feed production and fish production. As fish feed is the key input having strong influencing on the productivity of fisheries, balanced fish feed with superior quality is essential for the successful farm operation. As a principal source of animal protein, fish production has to be increased manifold to meet the requirement in Bangladesh. The fish feed production system at Mymensingh region was satisfactory. The findings of the study indicated that the profitability of fish feed production was quite satisfactory and had attracted interest of the entrepreneurs of Bangladesh. The fish feed industry is performing a vital role in the development of fishery sector in Bangladesh. Through more participation of the entrepreneurs and patronization from the government agencies, the industry would be able to contribute more in the development of fishery sub-sector of the country in near future.

\section{REFERENCES}

1. Biswas SS, 1990. An economic analysis of pond fish culture of BARC in some selected areas of Mymensingh district. M.S. Thesis, Department of Agricultural Economics, Bangladesh Agricultural University, Mymensingh. 42-52pp.

2. Bhuiyan MIA, 2002.Effects of different supplementary feeding methods on growth of fish in carp polyculture. MS Thesis. Department of Aquaculture, BAU, Mymensingh.94 pp.

3. Dillion H, 1993. Husbandry factors affecting survival and growth of carp (C. carpio) fry and an evaluation of dietary ingredients available in Bangladesh for the formulation of a carp fry diet. Ph.D. thesis, Institute of Aquaculture, University of Stirling, Scotland, UK.415 pp.

4. FAO, 2005. Formulated Animal and Aqua Feed Industry in Sub-Saharan Africa, Survey Report. Food and Agriculture Organization of the United Nations, Rome.

5. Islam MS, 1987. Socio-economic status of fish farming income selected areas of Denajpur district. M.S. Thesis, Department of Fisheries Management, Bangladesh Agricultural University, Mymensingh. 52-60pp.

6. Khaleque MA, AKS Masud and JA Mirza, 1998. Economics of fish production under semi-intensive culture and management.Bangladesh. Journal of Training and Development, 2: 81-86.

7. Lall SP, 1991. Concepts in the formulation and preparation of a complete fish diet, pp. 1-12. In S.S. De Silva. (ed.) Fish nutrition research in Asia. Proceedings of the Fourth Asian Fish Nutrition Workshop. Asian Fish.Soc. Spec. publ. 5, 205 pp. Asian Fisheries Society, Manila, Philippines.

8. Rahman MA, 1995. Economics of pond fish production under different management system in Tangail district. M.S. Thesis, Department of Agricultural Economics, Bangladesh Agricultural University, Mymensingh. 43-49 pp.

9. Rahman MM, 1998. Socio-economic aspects of carp culture development in Gazipur district. M.S. Thesis, Department of Agricultural Economics, Bangladesh Agricultural University, Mymensingh. 45$50 \mathrm{pp}$.

10. Roy R, 2002. Effect of stocking density on the growth and survival of GIFT tilapia fed on formulated diet. MS Thesis. Department of Aquaculture, BAU, Mymensingh.68 pp.

11. Shohel NU, 1998. A socio- economic study of pond fish production in some selected areas of Noakhlali district. An M.S. Thesis, Department of Aquaculture, Bangladesh Agricultural University, Mymensingh. 55-60 pp.

12. Zaher $M$ and MA Mazid, 1993. Aquafeeds and feeding strategies in Bangladesh, pp. 161-180.In M.B.New, A.G.J. Tacon and I. Csavas. (eds.) Farm-made aquafeeds. Proceedings of the FAO/AADCP Regional Expert Consultation on Farm-Made Aquafeeds, 14-18 December 1992, Bangkok, Thailand. FAO-RAPA/AADCP, Bangkok, Thailand.434 pp. 